\title{
A polymorphism of the ability to smell urinary metabolites of asparagus
}

\section{Summary and conclusions}

The urinary excretion of (an) odorous substance(s) after eating asparagus is not an inborn error of metabolism as has been supposed. The detection of the odour constitutes a specific smell hypersensitivity. Those who could smell the odour in their own urine could all smell it in the urine of anyone who had eaten asparagus, whether or not that person was able to smell it himself. Thresholds for detecting the odour appeared to be bimodal in distribution, with $10 \%$ of 307 subjects tested able to smell it at high dilutions, suggesting a genetically determined specific hypersensitivity.

\section{Introduction}

The urinary excretion of pungent odorous substance(s) after asparagus is eaten has been classified as an inherited trait or inborn error of metabolism..$^{1-4}$ Several metabolites that appear in the urine after eating asparagus have been identified, ${ }^{5-7}$ and at least two different ones have been held responsible for the characteristic odour. ${ }^{18} 7$ One of them, methylmercaptan, appeared in the urine of $40 \%$ of 115 subjects, and its excretion was considered an expression of an autosomal dominant gene. ${ }^{1}$

Personal observations of one of the authors (SHB) suggested that the excretion of odorous substances in the urine after eating asparagus might be universal, but that the ability to detect their odour varied. This raised the possibility of a specific smell hypersensitivity rather than an inborn error of metabolism. This hypothesis was subjected to test.

\section{Materials and methods}

SMELL-TEST SOLUTIONS

A man who had never been able to detect any special odour emitted by his urine after he had eaten asparagus (hereafter, the "odour") ate $450 \mathrm{~g}$ of canned asparagus after emptying his bladder. Six hours later he again urinated, and under sterile conditions $10-\mathrm{ml}$ ampoules were filled with this urine and were promptly sealed and kept frozen at $-20^{\circ} \mathrm{C}$.

Serial twofold dilutions in tap water of the contents of a thawed ampule (solution No 0), up to a dilution of 1:4096 (solution No 12), were freshly prepared in ground glass-stoppered test tubes for each group of subjects whose smell threshold was being tested. No subject had a cold or had smoked or eaten half an hour before testing, and no subject knew that the test solutions contained urine. Each was presented initially with a test tube containing the undiluted thawed urine to familiarise him with the odour to be detected. The tube with the highest dilution was then gently inverted, the stopper was removed, and the tube was held close under the nose and sniffed. The remaining tubes were similarly tested by the subject in order of increasing

Metabolic Laboratory and Medical Department B, Hadassah University Hospital and Hebrew University-Hadassah Medical School, Jerusalem, Israel

M LISON, MD, (present appointment: paediatric resident, Sheba Medical Centre, Tel Hashomer, Israel

S H BLONDHEIM, MD, professor of medicine

R N MELMED, MD, associate professor of medicine concentration, and the solution first identified as giving off an odour was then repeatedly presented along with three other tubes of tap water in random order in a test intermediate between the $1 / 3$ and $2 / 5$ tests described by Amoore. ${ }^{8}$ The lowest concentration consistently differentiated from tap water was considered the subject's smell threshold.

Serial twofold dilutions of acetone (CP) in tap water were also freshly prepared and the smell threshold similarly determined for each subject.

\section{SUBJECTS}

The smell threshold for the odour was tested in 328 subjects, of whom 307 were randomly selected from patients attending medical outpatient clinics. None of the latter was asked any question with regard to asparagus before being tested. This latter group included 173 Israeli Jews of Ashkenazic (European or American) origin, 57 of Yemenite and 57 of Moroccan origin, and 20 were of mixed origin. Their ages ranged from 17 to 69 years.

A group of 102 other clinic patients was tested for their ability to detect the odour of a control urine passed by the donor of the test urine when he had not eaten asparagus. The age and sex distribution of these subjects, as well as their ethnic origins, were similar to those of the test subjects.

Two other groups were chosen from among visiting American students who were accustomed to eating asparagus from time to time, unlike the great majority of the Israeli subjects who had rarely or never eaten asparagus. One of these groups included 10 Americans who knew that they could smell a pungent urinary odour after eating asparagus. The other group included 11 Americans who were sure that they had never detected any unusual urinary odour after eating asparagus.

\section{Results}

All subjects in the randomly chosen group of Israeli clinic patients were able to differentiate the odour of the undiluted thawed test urine from water. Some said the odour was that of "vegetable soup" while others could not characterise it. The Americans chosen because of their familiarity with the odour were quick to identify it in the test urines as resulting from the eating of asparagus.

On plotting, the smell thresholds of the randomly chosen subjects showed what appeared to be a bimodal distribution, with the antimode at dilution No 7 (1:128 dilution). Whichever way the population was divided, whether by ethnic origin, sex, or age (under 40 , or 40 years and older), in each subgroup a bimodal type of curve, with the antimode at dilution No 7, was obtained (figure and table I). The major peak in all subgroups was at dilution No 4, while the minor peak was at dilutions Nos 8 or 9 . The thresholds of $9.8 \%$ of the total population were on the dilute side of the antimode (Moroccan $8.8 \%$, Yemenite $8.8 \%$, Ashkenazic $11.6 \%$; female $11.7 \%$, male $6.7 \%$; young $12.7 \%$, old $1.3 \%$ ). These subjects were therefore designated "smellers," as opposed to those with thresholds at or on the more concentrated side of the antimode, the "non-smellers." The difference between the mean thresholds (in binary dilution steps ${ }^{\circ}$ ) of smellers and non-smellers in the total population $(8.74 \pm 1.75$ versus $4.01 \pm 1.48$; figure) was highly significant $(\mathrm{p}<0.0005)$.

Of the 102 subjects tested with the control urine, 42 were unable to detect any odour at all in the undiluted urine, while the greatest dilution at which any control subject was able to detect an odour was dilution No 4. The average threshold in binary dilution steps (assuming a dilution of -1 for those unable to detect any odour even in undiluted urine, dilution No 0 ) was very much lower than the mean threshold of even the non-smellers of urine passed by the donor after he had eaten asparagus $(0.16 \pm 1.35$ versus $4.01 \pm 1.48, \mathrm{p}<0.0005)$. 
When the proportions of smellers and non-smellers in the various subgroups based on ethnic origin, sex, or age were compared using the chi square test, no significant differences were found. There was no relation between smell sensitivity for the odour tested and for that of acetone in any group of subjects. For both odours, however, as well as for that of the control urine, the thresholds of those under the age of 40 tended to be more concentrated than those aged 40 and over, but the differences did not achieve statistical significance.

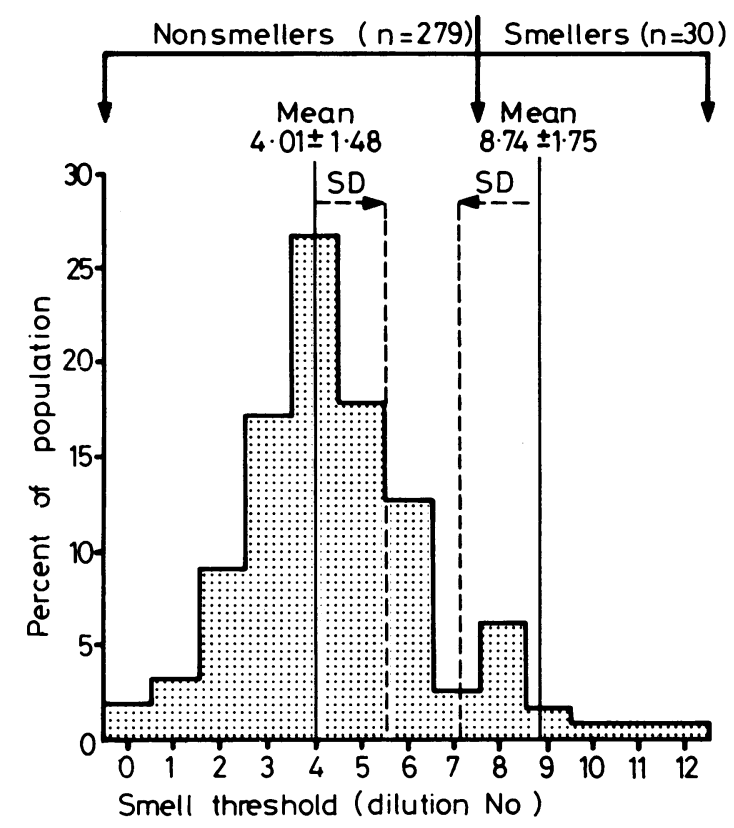

Smell thresholds for total population. Difference between mean thresholds (in binary dilution steps) of smellers (thresholds above antimode, at dilution No 8 or higher) and non-smellers (thresholds at dilution No 7 or lower) highly significant $(p<0.0005)$. that person was able to detect it himself). Thus the excretion of the odorous substance(s) cannot be due to an inborn error of metabolism.

The distribution curve of the smell thresholds for this odour consistently appeared to be bimodal, with the thresholds of a small minority of about $10 \%$ constituting the minor peak on the dilute side of the antimode. This bimodality suggests that there may be a genetic trait, a specific smell hypersensitivity. On the other hand there were no differences in the distribution of smellers and non-smellers for the specific odour in the three

\begin{tabular}{|c|c|c|}
\hline & $\begin{array}{c}\text { Threshold } \\
\text { (dil No) }\end{array}$ & $\begin{array}{l}\text { No of } \\
\text { subjects }\end{array}$ \\
\hline Non-smellers $(n=11)$ & $\begin{array}{c}0-3 \\
4 \\
5 \\
6 \\
7\end{array}$ & $\begin{array}{l}0 \\
1 \\
4 \\
5 \\
1\end{array}$ \\
\hline Smellers $(n=10)$ & $\begin{array}{r}8 \\
9 \\
10 \\
11 \\
12\end{array}$ & $\begin{array}{l}6 \\
2 \\
1 \\
1 \\
0\end{array}$ \\
\hline
\end{tabular}

ethnic groups of Israeli Jews studied, although these groups differ with regard to a great variety of genetic characters. ${ }^{1011}$ Studies of the thresholds of large kinships would be decisive in determining whether or not there is a genetic factor.

To resolve the conflict as to the chemical nature of the characteristic odorous metabolite(s) derived from asparagus, the smell thresholds of preselected smellers and non-smellers of the

TABLE I-Distribution of smell thresholds (\%) for odour of urinary metabolites of asparagus

\begin{tabular}{|c|c|c|c|c|c|c|c|c|}
\hline \multirow{2}{*}{$\begin{array}{l}\text { Smell } \\
\text { threshold } \\
\text { (dil No) }\end{array}$} & \multicolumn{8}{|c|}{ Population } \\
\hline & $\underset{(\mathrm{n}=57)}{\text { Moroccan }}$ & $\begin{array}{l}\text { Yemenite } \\
(\mathrm{n}=57)\end{array}$ & $\begin{array}{l}\text { Ashkenazi } \\
(\mathrm{n}=173)\end{array}$ & $\begin{array}{c}\text { Female } \\
(\mathrm{n}=188)\end{array}$ & $\begin{array}{c}\text { Male } \\
(\mathrm{n}=119)\end{array}$ & $\underset{(n=79)}{\operatorname{Old}(\geqslant 40)}$ & $\begin{array}{l}\text { Young }(<40) \\
(n=228)\end{array}$ & $\begin{array}{c}\text { All } \\
(\mathrm{n}=307)\end{array}$ \\
\hline $\begin{array}{r}0 \\
1 \\
2 \\
3 \\
4 \\
5 \\
6 \\
7 \\
8 \\
9 \\
10 \\
11 \\
12\end{array}$ & $\begin{array}{r}1.7 \\
8.8 \\
15.8 \\
17.5 \\
21.0 \\
15.8 \\
8.8 \\
1.7 \\
8.8 \\
= \\
=\end{array}$ & $\begin{array}{c}\bar{Z} \\
\overline{5.2} \\
21.0 \\
23.0 \\
19 \cdot 3 \\
19 \cdot 3 \\
3.5 \\
8.8 \\
= \\
=\end{array}$ & $\begin{array}{r}1.7 \\
2 \cdot 8 \\
6.9 \\
14 \cdot 4 \\
29.0 \\
18.4 \\
11.5 \\
2.8 \\
5.2 \\
2.8 \\
1.1 \\
1.1 \\
1.1\end{array}$ & $\begin{array}{r}1.6 \\
2.7 \\
8.0 \\
14.9 \\
27.1 \\
16.0 \\
14.4 \\
3.7 \\
9.0 \\
1.1 \\
0.5 \\
\frac{1.1}{1.1}\end{array}$ & $\begin{array}{r}1 \cdot 7 \\
4 \cdot 2 \\
8.4 \\
21 \cdot 0 \\
26.1 \\
21.0 \\
10 \cdot 1 \\
0.8 \\
1.7 \\
2.5 \\
0.8 \\
1.7 \\
-\end{array}$ & $\begin{array}{r}3 \cdot 8 \\
3 \cdot 8 \\
12 \cdot 6 \\
24 \cdot 0 \\
27 \cdot 8 \\
17 \cdot 7 \\
8 \cdot 8 \\
= \\
1 \cdot 2 \\
= \\
=\end{array}$ & $\begin{array}{r}0.8 \\
3.0 \\
6.5 \\
14.9 \\
26.3 \\
17.9 \\
14.0 \\
3.5 \\
8.3 \\
1.7 \\
0.8 \\
0.8 \\
0.8\end{array}$ & $\begin{array}{r}2 \cdot 0 \\
3.3 \\
8.1 \\
17 \cdot 2 \\
26 \cdot 7 \\
17.9 \\
12 \cdot 7 \\
2.6 \\
6.2 \\
1.6 \\
0.7 \\
0.7 \\
0.7\end{array}$ \\
\hline
\end{tabular}

The group of 20 of mixed origin has been excluded.

The thresholds of the 10 subjects familiar with the odour were all on the dilute side of the antimode, among the smellers (table II). On the other hand, the thresholds of all those who knew they were unable to detect the odour were all at or on the more concentrated side of the antimode, among the non-smellers.

The known smellers readily detected the odour in the urine passed by each of 11 non-smellers who had eaten asparagus, and they readily differentiated all such urines from those passed by subjects who had not eaten asparagus.

\section{Discussion}

It would appear that the ability to excrete (a) characteristic pungent substance(s) in the urine after eating asparagus is universal, since those familiar with the odour could detect it in the urine of anyone who had eaten asparagus (whether or not odour should be determined for the various isolated metabolites. ${ }^{5-7}$

"Taste blindness" for various substances in the minority of a population is well known, and there are reports of "smell blindness" or specific anosmia for certain odours as well. ${ }^{8}$ On the other hand, although general hyperosmia is known in certain pathological conditions, ${ }^{12-14}$ apparently there has not as yet been described a specific smell hypersensitivity or hyperosmia. ${ }^{8}$ If confirmed, this would be the first instance of a specific smell hypersensitivity.

This paper is based on a thesis submitted by ML to the Hebrew University-Hadassah Medical School in partial fulfillment of the requirements for the $M D$ degree.

Requests for reprints to SHB. 


\section{References}

1 Allison AC, McWhirter KG. Two unifactorial characters for which man is polymorphic. Nature 1956;178:748-9.

2 Wagner RP, Mitchell HK. Genetics and metabolism. 2nd ed. New York: J Wiley, 1964:594.

3 Kalow W. Pharmacogenetics. Heredity and response to drugs. Philadelphia, London: W B Saunders Co, 1962:133.

4 McKusick VA. Mendelian inheritance in man. 4th ed. Baltimore: Johns Hopkins University Press, 1978:31.

5 Nencki M. Ueber das Vorkommen von Methylmercaptan im menschlichen Harn nach Spargelgenuss. Archiv für experimentalle Pathologie und Pharmakologie 1891 ;28:206-9.

6 White HR. Occurrence of S-methyl thioesters in urines of humans after they have eaten asparagus. Science $1975 ; 189: 810-1$.

${ }^{7}$ Gearhart HL, Pierce SK, Payne-Bose D. Volatile organic components in human urine after ingestion of asparagus. Clin Chem 1977;23:1941.
${ }^{8}$ Amoore JE. Olfactory genetics and anosmia. In: Handbook of sensory physiology. Vol iv, Chemical senses-pt 1. Berlin: Springer, $1971: 245-56$

9 Amoore JE. Specific anosmia: a clue to the olfactory code. Nature 1967; 214:1095-8.

${ }^{10}$ Mourant AE, Kopec AC, Domaniewska-Sobczak K. The genetics of the fews. Oxford: Clarendon Press, 1978:1-114.

11 Goodman RM. Genetic disorders among the fewish people. Baltimore and London: Johns Hopkins University Press, 1979:1-493.

12 Henkin RI, Powell GF. Increased sensitivity of taste and smell in cystic fibrosis. Science 1962;138:1107-8.

13 Henkin RI, Bartter FC. Studies on olfactory thresholds in normal man and in patients with advanced adrenal cortical insufficiency. $\mathcal{F}$ Clin Invest $1966 ; 45: 1631-9$.

${ }^{14}$ Campanella G, Filla A, DeMichele G. Smell and taste acuity in epileptic syndromes. Eur Neurol 1978;17:136-41.

(Accepted 1 September 1980)

\title{
New medicine and new biology
}

\author{
MICHAEL STOKER
}

Medicine, as we all know, is one of the branches of biology. It is applied biology, like agriculture, because it has a clear goal and is not practised for curiosity alone. We also know that in biology there has been an unprecedented upheaval during the past three decades, amounting practically to a revolution in outlook. Has it influenced medicine? That is the question.

The revolution in biology can very loosely be called molecular biology, but it now goes far beyond the function and structure of macromolecules. Though it had roots in earlier research in Britain, and particularly Garrod's first accounts of the inherited disorders of metabolism and Griffith's studies on pneumococci, the beginning of the new era may be marked by the discovery in the USA of the chemical nature of heredity from the experiments of Avery, McCleod, and MacCartney on pneumococcal transformation and those of Hershey and Chase on bacterial viruses. This was followed by the great Cambridge and London period of the early 1950s, when were found the three-dimensional structure of DNA and protein and their basis in a linear sequence, which is the language of genetic information. Biology was then set for the great surges of discovery in the subsequent decades, which still continue. The advances may now be identified more broadly as cellular biology, because so many of the new and exciting findings have concerned the role of molecules in intact living cells, not least the cells of the nervous system and cancer cells. Indeed, the expansion of biological knowledge has been greatest in this interpretation of biological phenomena at the cellular and subcellular levels. Similar solutions to the complexities of tissue, organ, or whole animal and plant have still to come.

The advances have depended firstly on ruthless reductionism and on the determination of the scientists concerned to concentrate on the simplest models-namely, viruses, bacteria, and only isolated cells from complex organisms such as mice and man. Secondly, the advances have depended on new technologies and instruments, and would have been impossible

The Francis Fraser lecture given at the Royal Postgraduate Medical Federation on 6 June 1980.

\footnotetext{
Department of Pathology, University of Cambridge, Cambridge CB2 1QP

Sir MICHAEL STOKER, CBE, FRCP, FRS, consultant, Imperial Cancer Research Fund
}

without, for example, isotopes and computers. But of central, indeed crucial, importance has been a special set of technologies concerned with purification, which began with the ultracentrifuge and chromatography, and then the columns and gels. These allow the separation of pure populations of single species of molecules, and even of cells, from complex and largely uninterpretable mixtures previously available. Latterly this concern with purity has led to the technique of molecular cloning. This means taking a single molecule, which is pure by definition but cannot be studied, and arranging for it to copy itself and eventually produce a large population of identical siblings, which may then be analysed with ease. Not only nucleic acids but also proteins may also be prepared by this powerful new technique.

But I am getting into detail too soon. My aim at this stage is simply to emphasise the blooming of biology, and particularly molecular and cellular biology. I now wish to examine the relevance of all this dizzy excitement in practical down-to-earth problems of human disease. So let us consider three interrelated questions: (a) What if any is the impact of the new biology in the prevention and cure of disease as seen by the clinician? (b) To what extent should private or public funds, earmarked for medical research, be allocated to general biology ? (c) Should up-to-date knowledge of the new biology be included in medical education, particularly at the more specialised postgraduate level?

\section{The new biology}

Before examining these questions let me pick out some of the highlights from knowledge acquired in the past decade or two. I will confine myself to animal as opposed to plant biology, though this division has become increasingly irrelevant. It is a personal and idiosyncratic list, no doubt influenced in some cases by my contact with the scientists concerned, though I shall hardly mention any by name. You must forgive me if I miss your favourites.

\section{MOLECULAR GENETICS}

It is well known that hereditary information is encoded in DNA as a three-base coding system. This code specifies the amino-acid sequence of an enzyme or other protein, and was 